\title{
Berkun Oya'nın Bayrak Oyunu ve Masum Dizisinin Uyarlama Açısından İncelenmesi
}

\section{Analysis of Berkun Oya's Play Bayrak and its Adaptation for the Television Series Innocent}

\author{
Gül Sevgi KARACA ${ }^{1}$ (1)
}

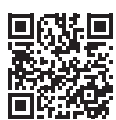

DOI: $10.26650 / C O N S 2021-897216$

'Araştırma Görevlisi, Kocaeli Üniversitesi, Güzel Sanatlar Fakültesi Sahne Sanatları Bölümü, Kocaeli, Türkiye

\section{ORCID: G.S.K. 0000-0002-3057-0827}

Sorumlu yazar/Corresponding author: Gül Sevgi KARACA,

Kocaeli Üniversitesi, Güzel Sanatlar Fakültesi Sahne Sanatları Bölümü, Kocaeli, Türkiye E-posta/E-mail: sevgi.karaca@kocaeli.edu.tr, sevgikaraca@yandex.com

Başvuru/Submitted: 15.03.2021

Illk Revizyon/Revision Requested: 04.05.2021 Son Revizyon/Last Revision Requested: 21.05.2021

Kabul/Accepted: 22.05 .2021

Online Yayın/Published Online: 02.06.2021

Atıf/Citation: Karaca, G.S. Berkun Oya'nın bayrak oyunu ve masum dizisinin uyarlama açısından incelenmesi. Konservatoryum Conservatorium, 8(1), 41-61. https://doi.org/10.26650/CONS2021-897216

\section{öz}

Tiyatro oyunları sıklıkla sinema veya televizyona uyarlanmaktadır. Berkun Oya'nın Bayrak oyunundan 2017 yılında, uyarladığı Masum dizisi, Türkiye'nin ilk profesyonel internet dizisi olarak kabul edilmektedir. Dünyada yavaş yavaş televizyon yayıncılığının yerini alan internet televizyonculuğunun, Türkiye için ilk adımı olan Masum'un gerek niteliği gerekse başarısıyla iyi bir öncül olduğunu söylemek mümkündür. Çalışmada, tiyatro oyunu ve internet dizisi olarak yazarı tarafından iki kez kurgulanmış olan Bayrak/Masum üzerinden uyarlama özellikleri, değişen dramatik araçlar aracılığıyla değerlendirilecektir. Dramaturjik analiz yönteminin tercih edildiği çalışmada iki yapıt arasındaki benzerlikler ve farklılıklar değerlendirilerek, iki farklı dramatik sanat formunun kullandığı yaklaşımlar belirlenecektir. Diziye uyarlama sırasında, eklenen karakterler ve bu karakterlerin eklenme sebepleri ile kullanılan yeni mekânların dramatik yapıya katkıları saptanmıştır. Karşılıklı uyarlama çalışmaları sırasında hem zaman ve uzam olanakları, hem hedef kitle, hem söylem, hem de dramatik yapıda farklar oluşmaktadır. Sözü edilen bu farkları Bayrak oyunu ve Masum dizisi ekseninde tespit etmek uyarlama ile ilgili saptama yapabilmenin de yolunu açacaktır.

Anahtar Kelimeler: Uyarlama, tiyatro, internet dizisi

\section{ABSTRACT}

Theater productions are often adapted for cinema or television. In 2017, Berkun Oya converted his play Bayrak to an Internet-based television series titled Masum (Innocent). The Internet-based streaming of shows is gradually replacing television broadcasting across the world. Masum is considered the first professionally produced series to be streamed over the Internet in Turkey. The production quality of Masum allows the assertion that Turkey's first foray into this domain showcases a promising premise with success. This study evaluates adaptation-related features of Bayrak/Masum and scrutinizes the changes in the dramatic tools utilized in the author's dual fictionalization for two distinct communication channels. The dramaturgical analysis method is applied to the study, which investigates the similarities and differences between the two works and elucidates the distinct approaches used for the two different dramatic art forms. This study also illuminates the rationale for adding characters to the Internet-broadcast adaptation of the play, noting the contributions made to the dramatic structure by this emergent theatrical 
space. Differences in target audiences, discourse, the possibilities of time and space, and dramatic form occur when reciprocal adaptations are attempted. Identifying these disparities in the axis of Bayrak and Masum offers opportunities of ascertaining conversion techniques.

Keywords: Adaptation, theater, Internet series

\section{EXTENDED ABSTRACT}

Berkun Oya began his playwriting and directing career just before the 2000s. He is now widely known, especially as a scriptwriter. After the success of his BluTV production Masum (Innocent), his work as a writer and director for Netflix's Bir Başkadır (Ethos) has recently attracted significant attention. Some common themes and stylistic features are evident in his self-directed plays staged in Theater Krek: for instance, the fear of abandonment and paternal problems are prominently highlighted in almost all of Oya's plays. Idealized protagonists are not generally encountered in his plays, which evince spaces where people can continue to exist with their flaws. All his characters, regardless of their motivations, are defeated by their failings at the outset.

Masum (Innocent) is noted as the first Internet-streaming mini-series in Turkey. Berkun Oya adapted it from his play Bayrak, which was written in 2008 and staged in Theater Krek in his direction in 2009. Bayrak was also staged as a 2017-2018 season Istanbul Devlet Tiyatrosu production directed by Kubilay Karslığlu. The play involves a couple who moves away from the city after retirement and about the two murders that transform the quiet life of the elderly duo. The narrative undoubtedly underwent many changes in being converted to a mini-series. It is necessary to analyze both works to determine such transformations in the characters, narrative tools, events, and accounts. Hence, this study conducts a channel-driven examination of fundamental dramatic tools, such as plot, character, message, and conflict focus to elucidate the mechanisms employed by the author to twice-fictionalize work for two distinct broadcasting platforms. In this context, the study first attends to the concept of adaptation and then performs a comparative dramaturgical analysis of the play vis-à-vis the series to determine similarities and differences.

In amending a play for cinema or television, the adaptor must conceive of its narrative in a larger physical space than the confines of a theater. This visual advantage should be used carefully and judiciously during the adaptation. It is impossible to discuss a successful adaptation unless specific theatrical elements are organically merged with the 
expressive tools of cinema and television. An adaptation is not the mere filming of a staged play. The textual elements of the play must be transformed into a film or television script with necessary additions and subtractions. The production of a new artistic work while preserving the main problems and effects of the play in question forms the basis of the adaptation. It is also a popular trend of contemporary theater practices, for which the importance of the director has been amplified. The texts of plays take on a new identity and are transformed by teams led by directors.

Theater adaptations are frequently used, especially in the early stages of a cinema. In Turkey, cinema and television scripts, both domestic and international, would also now be very popular if reciprocally adapted for theatrical productions. There would undoubtedly be some disparities in terms of the possibilities of time and space, target audience, discourse, and dramatic form in such mutual adaptations. The production quality of Masum allows the assertion that Turkey's first foray into the Internet-streaming domain showcases a promising premise with success. The identification of such distinguishing in the axis of the Masum (Innocent) and Bayrak could pave the way to ascertain the mechanisms of adaptation. 


\section{Giriş}

Berkun Oya’nın dijital bir platform olan BluTv için kendi oyunu Bayrak’tan uyarladığg, Bayrak'ın dizi versiyonu olan Masum, ülkemizin ilk profesyonel internet dizisi olmuştur. Televizyon dizilerinin, sansür ve giderek uzayan süreleri dolayısıyla sahip olduğu pek çok zaaf, dijital platformlarda yayınlanan dizileri daha özgür bir noktaya taşımaktadır. Bu anlamda oldukça ünlü bir platform olan Netflix'in ülkemiz pazarına girişi, konunun yerli yayın kuruluşları tarafından da görünür olmasını sağlamıştır. Netflix’in seyircisine ayrıcalık olarak sunduklarına bakılacak olursa, zamansız olması (istendiğinde internet olan her yerde izlenebilmesi), haftalık bölüm yayınlamaması (bir dizinin bir sezonunu bir kerede yayınlayıp, isteyen seyircinin istediğince izlemesini sağlaması), aylık sabit bir ücret karşılığında pek çok film, belgesel ve dizinin yanısıra kendi orijinal içeriklerini de seyircisine sunması ve ücretsiz deneme imkanı olması olarak sıralanabilir. Bu sayede Netflix, sürekli bir büyüme içinde ve dünyada çok geniş bir ulaşılabilirliğe sahip durumdadır (Netflix Investor Relations, 2020). Yeni bir izleme alışkanlığı vadeden bu yeni platformların sayısı her geçen gün artmaktadır. Platformların, kendilerine özel olarak ürettikleri içerikler arasında ilk yapımlar ise bir roman uyarlaması olan Fi ve bir oyundan uyarlama olan Masum olmuştur. Bgün Bugün Netflix, BluTV, Puhu TV, Gain, Exxen gibi mecraların kendilerine özel ürettikleri içeriklerinin sayısı hızla artmakta, bu içeriklerin çoğu ise dizilerden oluşmaktadır.

İlk yapımlardan olan Masum, Berkun Oya’nın 2008 yılında kaleme aldığı Bayrak oyunundan kendisi tarafından uyarlanmıştır. 2009 yılında, Berkun Oya yönetmenliğinde Tiyatro Krek’te sahnelenen oyun, 2017-2018 sezonu itibariyle İstanbul Devlet Tiyatrosu yapımı olarak, Kubilay Karslıoğlu yönetmenliğinde de seyirci karşısına çıkmıştır. Emekliliğin ardından şehirden uzakta yaşayan bir aile ve onların hayatını değiştiren iki cinayeti konu edinen oyun, hiç kuşkusuz diziye uyarlanırken pek çok değişikliğe uğramıştır. $\mathrm{Bu}$ uyarlama esnasında oyuna dahil edilen karakterler, anlatım araçlarının değişimi, eklenen yan olay ve hikayeler gibi durumların tespiti adına, iki yapıtın da analizlerinin yapılması gerekmektedir. Bu bağlamda, olay örgüsü, karakter analizleri, mesaj ve çatışma odakları gibi temel dramatik araçlar analiz edilerek oyun ve dizi olarak yazarı tarafından iki kez kurgulanmış olan bu yapıtın, platform bağlamında değişen araçları tespit edilmeye çalışılacaktır. Bu bağlamda öncelikle uyarlama kavramı üzerinde durulacak ardından oyun ve dizinin karşılaştırmalı dramaturjik analizi yapılarak benzerlik ve farklilıklar saptanacaktır. Bu yolla tiyatrodan televizyona uyarlamanın olanak ve ihtiyaçlarının belirlenebilmesi hedeflenmektedir. S1k kullanılan bir yöntem olmasına rağmen tiyat- 
rodan sinema ve televizyona uyarlama ile ilgili yeterli bir literatür oluşmamıştır ve bu yönde uyarlama ile ilgili kaynaklar kısıtlıdır. Örnekler üzerinden yapılacak değerlendirmeler, uzun vadede kural veya gereklilikler oluşturmayı mümkün kılabilecektir.

\section{Tiyatrodan Televizyona Uyarlama}

Uyarlama, "1. Başka bir dile aktarılan eserin kişi ve yer adlarını, yaşayış kurallarını değiştirerek uygulamak; 2. Bir eseri, türünden başka bir türe çevirmek, romandan oyun, oyundan opera çıkarmak" olarak tanımlanmaktadır (Türk Dili ve Edebiyatı Ansiklopedisi, 1977, s. 30-32, Aktaran: Bulut, 2017, s. 8). Uyarlama işlemlerinin çeşitleri ise Georges Bastin tarafından, "atlama/kısaltma, genişletme, yabancılık/yerlileştirme, güncelleme, durumsal eşdeğerlik, yaratma” olarak belirlenmiştir. Yöntemler, hedef kitleye ve/ veya uyarlayıcının aktarmak istediği mesaja göre seçilmektedir.

Mekân ve zaman tiyatro sahnesi ve hareketli görüntü arasındaki en temel farklardan birini oluşturmaktadır ve çoğunlukla bu uyarlamalarda genişletme yöntemine başvurulduğu belirtilmektedir. Tümü dramatik sanatlar olan, tiyatro, sinema ve televizyon, aynı malzemeden aynı biçimde çoğunlukla yararlanamazlar. Field, uyarlamanın başlı başına bir sanat olduğunu ifade eder:

"Uyarlama hem bir hüner hem de bir mücadele alanıdır. Uyarlamak fiili, "bir ortamdan başka bir ortama aktarmak, geçirmek" anlamına gelir. Uyarlama, "değiştirerek ya da ayarlamalar yaparak uygun hale getirmek ya da uymasını sağlamak"; olarak tanımlanır; yani yapı, işlev ve biçimde bir değişiklik yaratmak üzere bir şeyi tadil etmek. Roman, kitap, oyun, makale ya da şarkı, uyarlamanın sadece başladığı yerdir. Kaynak malzemedir bunlar, başlangıç noktasıdır; daha fazlası değil. Başı başına bir sanattır uyarlama" (Field, 2012, s. 329).

Uyarlamayı bir çıkış noktası olarak kabul eden bu düşünceyle yola çıkan Field, uyarlamanın ilkeleri ile ilgili görüşlerini ise şöyle açıklar:

"Bir oyunun aksiyonu, konuşulan sözcükler üzerinden açıklandığı için sizin de bunu görsel olarak açmanız gerekir. Oyun metninde sahne olarak bulunmayan, sadece atıfta bulunulan sahneler ya da diyaloglar eklemeniz, sonra onları metinde bulunan ana sahnelere sizi götürecek biçimde yapılandırmanız, tasarlamanız ve yazmanız gerekebilir. Aksiyonu görsel olarak genişletmenin yollarını bulmak için oyun metnindeki diyalogları inceleyin" (Field, 2013, s. 346). 
Field'ın değindiği 'aksiyonun sözcükler içinde açıklanması' düşüncesi güncel tiyatro pratiğinde geçerliliğini tamamen korumamaktadır. Tiyatronun sözle var olduğu eski bir düşüncedir, tiyatro, sözle ilişkili olduğu kadar görsel olanakları da kullanan, esasen görsel bir dramatik sanattır. Bir oyun metni ancak sahnede tamamlanır, oyuncu-dekor-kostüm-1şıkla bir bütündür. Özellikle sahne teknolojilerinin geliştiği, disiplinlerin iç içe girdiği göz önünde bulundurulmalı, sözsüz oyunların varlığı unutulmamalıdır. Fakat bir oyun metni ele alındığında kuşkusuz uyarlayan kişinin metni, sinema ve televizyonun, tiyatrodan daha geniş bir somut uzamda değerlendirmesi gerekmektedir. Bu görsel avantaj, uyarlama esnasında özenli ve iyi kullanılmalıdır. Tiyatronun kendine has öğeleri, sinema ve televizyonun anlatım araçlarıla organik bir biçimde bir araya getirilmedikçe başarılı bir uyarlamadan söz etmek mümkün değildir. Zira bir uyarlama, tiyatro oyunun kameraya alınması anlamına gelmez. Gerekli ekleme ve çıkarmalarla, tiyatro için yazılmış metin, senaryoya dönüştürülmelidir. "Televizyon dizilerinde, zamansal devinimin ve düzenlemenin yasaları tiyatronun yasalarından değişiktir. Bütünün parçacıklarını seçip, aralarında ilişki kurulurken, yazar elinde nelerin bulunduğunu bu parçacıkları kopmaz bir biçimde birbirine nelerin bağladığını çok iyi bilmek görmek zorundadır" (Akyürek ve Orhon, 2009, s. 129-130). Akyürek ve Orhon da tiyatrodan televizyona uyarlamada en sık kullanılan yöntemin genişletme işlemi olduğunu belirtirler. Görsel olanakları kullanmak, oyunda görülmeyen aksiyonu etkileyecek dış sahneleri yazmak bu işlemin temelini oluşturmaktadır (Akyürek ve Orhon, 2009, s. 130). William Miller da tiyatro oyununun uyarlanması sırasında genişletme işleminin zorunlu olduğunu düşünmekte, başarılı bir uyarlamanın ancak öykü evreninin genişletilmesiyle mümkün olduğunu savunmaktadır (Miller, 2012, s. 262).

Genişletme işlemiyle ilgili Hitchcock'un düşünceleri ise oldukça ilgi çekicidir. Hitchcock, 'açıp genişletme' işleminin sinemacıların düştüğü bir hata olduğunu belirtir, bu durumun 'boş ve anlamsız' yapaylıklara sebep olduğunu vurgular. Kendisinin Frederick Knott'un oyunundan uyarladığı Dial M for Murder (Cinayet Var) filminde yaptıklarını da örnek olarak verir:

“Cinayet Var'da dış çekimlerden kaçınmak için elimden geleni yaptım. Müfettişin araştırma yaptı̆̆ sahnelerde, o da çok kısa olmak üzere, iki üç dış çekim vardı. Hatta gerçek ayak seslerini alabilmek amacıyla döşemeyi mermerle bile kaplattırdım. Başka bir deyimle yaptığım her şey, oyunun tiyatroda sağladığı etkiyi vurgulamak amacını taşıyordu" (Truffaut, 2018, s. 196). 
Linda Seger'in vurguladığı gibi tiyatro, sinema ve televizyon, birbirinden farklı gerçekliklere sahiptir. Tiyatro, seyircisiyle var olur ve gerçekçi olmayan mekânlar seyirci tarafindan baştan kabul edilmiştir, mesela bir bayrak, bir ülkenin sarayını temsil etmek için yeterli olabilecektir. Seger'in burada genişletme işlemi ve gerçekçi düzleme taşımak konusunda verdiği örnek oldukça önemlidir. Seger, Peter Schaffer'ın Küheylan oyununun sinema uyarlamasını izlememeyi seçtiğini, bir kez atların gözü gerçekçi biçimde oyulduğunda, tiyatroda atların gözlerinin oyulmasının karşıladı̆̆ı sembolik anlamı yitireceğini düşündüğünü belirtmiştir (Seger, 1992, s. 68).

Ele alınan oyunun, temel sorunlarını, etkilerini koruyarak yeni eserler üretmek, uyarlamanın temelini oluştururken, yönetmenin öneminin arttığı güncel tiyatro pratiğinde de oldukça popüler bir yönelimdir. Oyun metinleri, yönetmen öncülüğünde bir ekip tarafından yeni bir kimliğe bürünmekte, bir bakıma uyarlanmaktadır.

Sinemanın özellikle ilk dönemlerinde, tiyatro uyarlamalarına sıklıkla yer verildiği görülmektedir. Günümüzde ise gerek Türkiye, gerekse Dünya sahnelerinde, sinema yapıtlarının, televizyon dizilerinin tiyatroya uyarlanışının oldukça popüler bir hal aldığı görülebilir. Uyarlama sırasında, hem her türün kendine has özellikleri, hem de oluşan yeni eserin hedef kitlesi çeşitli farkları zorunlu kılar. Sözü edilen farkları Bayrak oyunu ve Masum dizisi ekseninde tespit etmek uyarlama ile ilgili saptama yapabilmenin de yolunu açacaktır.

\section{Uyarlamada Dramatik Malzemeye Yaklaşım Açısından Bayrak ve Masum'un Karşılaştırmalı Analizi}

2000'lerden hemen önce oyun yazarlı̆̆ ve yönetmenlik kariyerine başlayan Berkun Oya günümüzde özellikle senarist kimliğiyle geniş kitlelerce tanınmıştır. BluTV yapımı olan Masum'un ardından, hem yazar hem de yönetmen olarak yer aldığı, Netflix yapımı Bir Başkadır, senaryosunu yazdığı Netflix yapımı Azizler son dönemde dikkat çeken işleri olmuştur. Tiyatro Krek'te kendi rejisiyle sahnelemiş olduğu oyunlarında ortak üslup özelliklerinin yanı sıra kimi ortak temalardan da söz edilebilir. Özellikle terk edilme korkusu ve baba problemi, yazarın hemen hemen tüm oyunlarında belirgin bir şekilde vurgulanmaktadır. İdealize edilmiş, kahraman niteliği taşıyan bir oyun kişisine rastlanmayan oyunlarında, kişilerin zaaflarıyla var oldukları bir zemin görülür. Karakterlerin tümü, motivasyonları ne olursa olsun, oyuna zaaflarına yenilmiş başlarlar. Tüm karakterleri, hayatlarının bir noktasında toplum kurallarının, insani değerlerin, kanunun ya da 
kendi vicdanının dışına çıkmış, hukuki olarak olmasa da mutlaka bir suç işlemiş̧lerdir, yazarları nezdinde suçludurlar.

Bayrak’ta da sözü edilen genel özellikler görülmektedir. Sakin bir yaşamı olan, emekli bir polis ve ailesinin iki cinayetin ekseninde değişen hayatlarını konu alan oyun, iki perde ve altı tablo olarak, geriye dönüşlerle kurgulanmıştır. Karısı tarafından aldatıldığını öğrenen evin küçük oğlu, yaşanan arbedede karısını öldürdüğünü sanarak, ailesinin evine sığınmıştır. Geriye dönüşler aracıllğıyla cinayetlerin üzerindeki sır perdesi aralanmakta, ailenin iç dinamiklerini aktarırken, hem de polisiye bir gizle hikayenin zeminini oluşturur. Plana göre, Abi, cesedi getirecektir ve ceset bahçeye gömülerek cinayet örtbas edilecek ve aile bu suçtan kurtulacaktır. Ancak Abi'nin bu yolculuğu tamamlayarak eve dönememesi planları sekteye uğratacaktır. Abi'nin cesedi getirirken ölmesiyle cinayetlerle ilgili gerçekler aile için gizli kalmayı sürdürecektir. Fakat yazar bu noktada gerçekleri aileden gizlerken, seyirciyle paylaşır. Kadın'ın, Âşık’ı öldürmekle suçladığı Adam, bu cinayetten ve karısının ilişkisinden habersizdir. Karısının sevgilisini öldüren kişi kendisi değil, abisidir. Aralarındaki tartışma sonucunda şiddet gösteren Adam, sandığı gibi karısının ölümüne değil baygınlık geçirmesine sebep olmuştur. Ardından duruma müdahale etmek için gelen Abi ise kendi hayatıyla ilgili gerçekleri paylaştıktan sonra Kadın'1 öldürür. Adam oyun boyunca işlemediği cinayetlerle suçlanır. Ailenin başına gelenler sonucunda Anne, oğlunun ölümüne duyduğu üzüntüyle ölür.

Masum'da ise aileye ait suçlar ve hikâyenin çatısı korunurken eklenen karakterlerle Abi (dizide Taner) ve eşi (dizide Rüya), Adam (dizide Tarık) ve Kadın (dizide Emel) arasındaki ilişki dinamikleri detaylandırılmış, eklenen polis Yusuf ve Selahattin ile öykünün polisiye tarafi beslenmiştir. Taner ile Yusuf arasında kurulan çocukluk arkadaşlığı bağ ile bir ana karakter olarak yapılandırılan Yusuf organik bir biçimde hikâyeye eklenmiştir.

Bayrak, gizi baştan sona koruyan yapısıyla, seyirciyi merak unsuruyla oyunda tutmaktadir. Her tablo, bir sorun üzerine kuruludur ancak sorunun ne olduğu seyirciye tablo sonuna dek açıklanmaz, bazen devam eden tabloda sorunun içeriği paylaşı1ır. Durumun ön planda olduğu birinci tablo, aynı zamanda oyunun en gergin tablosudur. Seyirciye ipuçlarıyla sezdirilen sebep, gergin atmosferi sürdürmek adına gizlenir.

Dizi 6 ay öncesi ve sonrasında, iki zamanda geçmektedir. Geriye dönüş ve ileriye atlayışlarla oluşturulan hikaye, zamansal açıdan aslında Tarık ve Emel'in evlenmesiyle başlar. 6 ay öncesi, evliliğin hızlı oluşunun vurgulandığı ve psikozları dolayısıyla, olmayan 
kişileri, olayları gören Tarık'ın, durumunun karısı tarafından fark edilmesiyle evliliğinin çöküşe sürüklendiği periyodu anlatmaktadır. Selim'in Emel'i manipüle ederek oluşturup ilerlettiği duygusal ilişkileri, olayı iki kişinin evliliğinin bitmesinden çıkarıp, suçla ilgili bir boyuta taşıyacaktır.

6 ay sonrasını anlatan süreçte olaya polis Yusuf dahil olur. Amiri Selahattin'in uzattığ dosya için büyüdüğü köye giden Yusuf, kısa sürede daha önceden tanıdığı Cevdetlerin evine girer. Cevdet, Yusuf'u sıcak karşılamışsa da Nermin, eve bir polisin girmesinden dolayı huzurlu değildir. Yusuf, bir yandan amirinden aldığı emir üzerine belli etmeden araştırma yapmakta, bir yandan eski evliliğini kurtarmaya çalışmakta, bir yandan da annesinin yanından kaçıp kendisinin yanına gelen 15 yaşındaki kızıyla uğraşmaktadır. Yusuf, çok kısa sürede, ailenin, özellikle Tarık'ın hareketlerindeki tuhaflığı fark eder. Kızı, Cevdet ve Tarık'la gittikleri yayla gezisinde kızı Elif'in kaybolmasıyla hem ani tepki vererek, aileyle ilişkilerini koparır, hem de ağaçların arasında bulduğu izlerle çocukluk arkadaşı Taner'in ölmediğini anlar. Elif'e olanlardan Tarık'ı sorumlu tutması dolayısıyla daha fazla derinleştiremediği soruşturmasını yarıda keserek şehre döner. Selahattin, Cevdet'e karşı radikal bir adım atamamaktadır. Geçmişten gelen vefa borçları ve Cevdet'in prestiji buna engeldir. Yusuf'tan geri çekilmesini ister.

Bir yandan aile, eve bir polisin girip çıkmış olması dolayısıyla gerginlik yaşarken, Tarık'ın durumu da giderek kötüleşmektedir. Yusuf'un evliliğini kurtarmasına ise Taner yardımcı olur. Eski karısı Feride'nin sevgilisinin bir kadınla olan görüntüleri sosyal medyaya sızmış ve Feride eve dönmüştür. Bu görüntüleri yayan Taner'dir. Eski arkadaşına bir iyilik yapmak istemiştir.

Taner'le Yusuf karşı karşıya gelirler. Yusuf, Taner'i sıkıştırmak ister ancak bu mümkün değildir. Taner, son bir işi kaldığını, zaten gideceğini söyler. Yusuf'un kafasına vurarak bayıltan Nermin'in yardımıyla Taner, Yusuf'u ormanda bırakarak ayak altından çekilmesini sağlar. Taner'in bahsettiği "son iş" Selim'dir. Ölmemiş olan Selim, polise gitmemiş, kaçmış, saklanmıştır. Fakat, Taner yine de onu öldürmeyi kafasına koymuştur. İzini sürer, bulur ve düşünmeden öldürür. Bu sırada Tarık evden kaçmıştır, Cevdet'i çok kötü etkileyen bu durum, onun, Tarık'ın ilaçlarını kullanarak dünyayla bağlarını koparmasına neden olmuştur. Taner, vedalaşmak üzere gelir, Nermin, Cevdet'i toparlamaya çalışmaktadır. Aile bu durumdayken, Tarık gelir, önce abisini, sonra anne ve babasını vurur. Abisi ve annesi ölmüştür. Yusuf, Tarık’1 intihar etmek üzereyken bulur. Kendisini öldürmesini 
engeller. Amiri ve Yusuf'un konuşmasından, Cevdet'in kurtulduğu anlaşılır. Selahattin'in konuşmaları, Yusuf'un bazı ipuçlarını birleştirmesini sağlar. Selahattin, Taner'in kabusu, Rüya'nın sevgilisidir.

Kişiler açısından diziyi ele aldığımızda öncelikle Yusuf karakteri dikkat çeker. Yusuf, oyunda bulunmamakta fakat dizide ana karakter olarak yer almaktadır. Yusuf'un dizideki varlığının temel amacı özdeşlik kurulabilecek bir karakter olmasıdır. Oyunda özdeşlik kurulabilecek kimse bulunmamakta, karakterlerin tümü için özdeşlik kurma ihtimalini Berkun Oya özenle ortadan kaldırmaktadır. Ancak Yusuf, eski karısına hala aşık ve onu geri kazanmaya çalışan, kızını çok seven, adalet duygusu güçlü bir polis olarak konumlandırılmıştır. Sinirli ve eski karısının sevgilisine kıskanç ve saldırgan davranan biridir; ancak iyi özelliklerinin yanında, bu özellikler seyirci için tolere edilebilir özelliklerdir. Taner Bayrakçı'nın çocukluk arkadaşı, Cevdet Bayrakçı'nın bir nevi öğrencisidir. Bayrakçı ailesiyle ilişkileri eskiye dayandığı kadar manevi borç taşımaktadır ancak Yusuf, kendisine verilen dosyada bu isimlerin yer alması karşısında tereddüt duymadan araştırma yapmaya başlayacaktır. Seyirci kuşkusuz bu karakteri olumlu bulmakta, geçmişlerine rağmen aileyi doğru olanı yapmaya kaba kuvvet kullanmadan ikna etme çabasına sempatiyle yaklaşmaktadır. Her biri, bir şekilde suçlu karakterler arasında, Yusuf en masum kişi gibi görünmektedir. Yusuf'un zaafı Feride ve mesleğidir, karakterin çatışması buradan çıkar. Eski karısı Feride'nin sevgilisini suçlu duruma düşürmek için mesleğini alet etmekten çekinmez ancak tüm geçmişi görmezden gelerek Bayrakçı ailesine tolerans göstermez. Elbette suçların boyutları farklıdır, mali bir suç üretmek/aramak ve cinayet karşılaştırılamaz ancak mesleğini zaaflarına alet edebildiğini bu biçimde görebiliriz. Kendisine dosyayı veren kişi olan Selahattin'i bile dinlemeyerek soruşturmayı sürdürmesi, güçlü adalet duygusu kadar kibir ve inatçıllığ işaret eder. Yusuf, diğer karakterlere göre daha masum veya daha idealist bu tutkularında ısrarcı olmasıyla kendi çatışmasını yaratır. Yusuf ancak insan ilişkilerinde kısmen suçlu sayılabilir, bunun dışında diğer kişilere göre daha idealdir.

Bayrakçı ailesi, duygusal ve ruhsal anlamda zedelenmiş bir ailedir. Bu doğrultuda, ortadaki suçlarda kendilerince masumdurlar. İçinde bulundukları durum onları seçeneksiz biçimde bulundukları noktaya sürüklemiştir. Kötü veya kötü niyetli değillerdir ancak kendilerini veya ailelerini koruyabilmeleri için bazı suçlar işlemeleri gerekmektedir.

Taner Bayrakçı, annesinin oğludur. Ailede çocuklar adeta paylaşılmıştır. Tarık, babasının oğluyken, Taner, annesine aittir. Her şeye rağmen şartlar elverdiğince annesi tarafindan 
korunur, kollanır. Ayrım burada başlamaktadır, annesi Taner'i şefkatle korur, babası da onu korumaktadır ancak bunu sevginin ya da aile bağlarının gerektirdiği şekilde yapmaz. Kendi itibarını korumak, babası için daha önceliklidir. Oğlunun katil olmasındansa, Cevdet Komiserin oğlu katil olmuş denmesinden korkar. Taner, annesi tarafindan aşırı bir sevgi, babası tarafindan ise ileri derecede bir görev bilinciyle korunmaktadır. Bu ikilem, her ne kadar işlediği cinayetlerle ilintili olsa da, hayatı boyunca böyle bir ikilem içinde yaşadığı ailenin genel yaklaşımından anlaşılmaktadır. Taner, ruhsal ve duygusal açıdan hasarlı büyüdüğü bu aileden, kendi kurduğu hasarlı aileye geçer. Karısı Rüya'nın, biriyle ilişkisi vardır ve bu Taner'in daha evlenmeden önce bildiği ve kabul ettiği bir durumdur. Rüya, bu kişi ne zaman kendisini çağırsa, Taner'in yanından ayrılarak oraya gitmektedir. Taner, bu duruma müdahale edememekte, adamın kimliğini dahi bilmemektedir. Taner, düzelmesi için çocuk yapmak veya uzaklara gitmek gibi önerilerde bulunmuşsa da Rüya tarafından kabul görmemiştir. Öyle bir çaresizlik ve pasiflik içindedir ki, Rüya ve adamın buluştuğu, görüştüğü evi bilmesine rağmen, kapıyı çalamaz. Buna hem cesareti yoktur, hem de Rüya'ya söz vermiştir. Evlilikleri süresinde, Rüya ve adamın ilişkisi zaman zaman bitmiş, Taner'in umutlandığ zamanlar olmuştur. Ancak bir süre sonra çalan bir telefonla ilişki yeniden başlamakta ve Taner'in çaresizliğini katlamaktadır.

Taner'in bu ilişkiyi başlangıçta neden kabul ettiğine, tüm bu sözleri nasıl verdiğine dair doğrudan bir bilgi verilmemektedir. Ancak onun için her şeyi yapmaya hazır, şefkatiyle yoran annesini örnek aldığı düşünülebilir. Adam, Rüya'ya şiddet uygulamaktadır. Rüya, vücudunda morluklarla etraftayken, çevre Taner'i suçlamakta, Taner gerçekte olanları söyleyememektedir. Zaten alkoliktir, bir de karısını dövmektedir insanlara göre. Taner, sıra dışı yaşantısı yüzünden, bir stereotipe dönüşmüştür aslında, karakterin trajedisi ve çatışması buradan ileri gelir. O, karısının ilişkisini kabul etmiş, görmezden duymazdan gelmiş̧ir ancak çevre için karısını döven bir alkolikten başka bir şey değildir. Emel ve Selim'in katili olan Taner, karısını ve karısının sevgilisini öldüremez- onlarla yüzleşemez bile. Bu da, Taner' in kardeşinin aldatılması nedeniyle bu cinayeti gerçekleştirmediğini kanitlar niteliktedir. Taner'in suçunun özü, geçmişte kabul ettiklerinin yerine koyduğu paralel hikâyeden intikam almaktır. Rüya ve sevgilisine yapamadıklarını/ yapamayacaklarını Emel ve Selim'e yapar. Çünkü Taner, Emel ve Selim'e, ne bu ilişkiye göz yumma sözü vermiştir, ne de Emel'e aşkla bağlıdır. Kendi ilişkisinde böylesi bir cinayet olmamasının sebebi kendini etkisiz hale getirdiği sebepler, Selim, Emel ve Taner ilişkisinde söz konusu değildir. Kısaca Taner, Selim ve Emel'den ne kardeşinin intikamı- 
nı alır, ne de durumu kurtarmaya çalışır. Taner, kendi hayatının intikamını başkasının hikâyesinden almaya çalışmaktadır. Selim'in öldü sanılırken ölmeyip kaçmasının ardından, Taner'i polise şikayet bile etmediği halde, Taner tarafindan takip edilip aradan altı ay geçmesine rağmen öldürülmesi bu yüzdendir. Taner, Selim ve Emel'i öldürdüğünde, Rüya ve sevgilisiyle ilgili sorunların biteceğini sanmıştır. Bu yüzden de Selim'in ölümünün ardından, Rüya'ya tekrar uzaklara gitmeyi teklif eder. Taner, sorunun çözüldüğünü düşünmektedir.

Taner, tüm yaşadıklarını kimseyle paylaşmadan sırtlamaya çalışmaktadır. Cinayete dek ailesiyle yaşamına dair herhangi bir şey paylaşmamıştır. Kendisini yalnızca, öldürmeden hemen önce, Emel'e anlatır. Bu cinayetin habercisidir adeta. Şimdiye dek, hayatını kimseye çıplaklığıyla anlatmamış Taner, ilk kez içini döker ve içini döktüğü-çok şey bilenkişiyi öldürür.

Taner'in Bayrak'ta karşıllı̆ı olan Abi ise, oyundaki en büyük kaybedendir. Karısını kaybetmiştir, bilincini kaybetmiştir ve sonucunda hareketleri üzerindeki kontrolü kaybetmiştir. İçgüdüsel davranmaktadır. Kadın'ı ve Aşık'ı öldürmüş ancak durumla ilgili açıklamayı kardeşine dahi yapamadan hayatını kaybetmiştir. Karısıyla ilişkisinde var olamaması, Abi’nin davranışlarının kaynağını oluşturmaktadır. Tıpkı kardeşi gibi, her şeyin sorumluluğunu alan annelerinin oluşturduğu karakterle de baş etmeye çalıştığı görülür.

Cevdet Bayrakçı, Tarık ve Taner'in babası, Nermin'in eşidir. Tarık'a karşı şefkatli, Taner'e karşı sert bir babadır. Nermin'le arasındaki ilişkide aşktan veya belirgin bir sevgiden söz etmek mümkün değildir. Alışkanlık içinde süren bir ilişkileri, bir de paylaştıkları bir evleri vardır. Kendine ayırdığ 1 oğlu Tarık konusunda cesur veya dürüst değildir. Belki de doğru bir tedaviyle "normal" biri olabilecek olan Tarık'ın her zaman eksiklerini tamamlamaya çalışmış tamamlayamadığı yerde örtbas etmiştir. Askerlikten atılırken alınan raporun gizlenmesi, Emel'le konuşurken, bir sorun olmadığını vurgulaması ve Tarık'a bir bebek gibi davranması bunları vurgulamaktadır. Geçmişte iyi bir polis, şimdi ise itibarlı bir polis emeklisidir. Ancak Tarık'a yaklaşımı, Taner'e kendi itibarını korumak için yardım etmesi gibi değildir. Tarık'a, hastalık ciddiye alınmazsa bitecekmiş gibi yaklaşmaktadır. İnkâr etme sebebi, Cevdet Komiser'in oğlu "deli" denecek korkusundan değildir. Tarık'ı korunaklı bir alanda tutma gayretindendir. Emel'e aşırı sıcak yaklaşımı, Tarık'ın ihtiyaç duyduğu gibi sevileceğine olan inancından ileri gelmektedir. Taner'e olan tavırlarındaki sertlik defalarca vurgulanır ancak özellikle Tarık'ın Emel'i öldürdü- 
ğünü sandığındaki yaklaşımıyla, Taner Emel'i öldürdüğündeki yaklaşımı ayrımı ortaya netlikle koyar. Selahattin'le olan konuşmasında, Cevdet'in duyarlı tarafinı görürüz, anlattığı anı, hem Cevdet'in kız çocuk isteğinin bir kez vurgulanmasını sağlar hem de karısı hamile olan arkadaşı için kendisini silahların arasına atmasını gösterir. Cevdet, kız çocuk istemiş̧tir, kız çocuğun daha sessiz sakin ve uyumlu olduğunu düşünmesinden gelmiştir bu istek. Bir yerde, Tarık’ı kastederek yaptı̆̆ı "bizim kız da evde kaldı" yorumu, Cevdet'in kız çocuğa yüklediği özellikleri Tarık’ta bulmasılya ya da kız çocukta aradığı özellikleri Tarık'a yüklemesiyle de açıklanabilir. Nermin'in ifadesine göre, Taner, tıpkı babasına benzemektedir. Bu tanımlamaya göre, Cevdet de, Taner de, derdini sıkıntısını paylaşmayan karakterlerdir. İçine kapanık ve sorunları örterek çözmeye çalışan baba-oğul kendi trajedilerine zemin hazırlamaktadırlar. Bu sorunları örterek çözme çabasının sonucunda, Taner katil olmuş, Cevdet ise oğlunu yitirmiştir. Yazarın, bu noktada sorunlarla yüzleşme biçimleri konusunda da örtülü bir mesaj verdiği düşünülebilir. Cevdet ve Taner'in yolu yanlıştır ve sonu felakete çıkmaktadır. Oyundaki Baba karakterine bakıldığında, karakterin eski polis olmasının da etkisiyle, ailesinin yaşadığı trajik cinayetin yasadışı çözümlerine Anne'ye göre çok daha mesafeli yaklaştı̆̆ı görülmektedir. Yine de, aile bütünlüğünü elinden geldiğince koruyacağının sinyallerini vermektedir. Oğullarının geldiği nokta onu yıpratır fakat kendini kaybettiğini görmeyiz. Anne’yi ve Aşık'1 gömerken, kendinden ödün vermişse de mesafeli tarafını korumak gayretini elden bırakmamıştır. Baba, Adam ve Abi'nin hayatında, Anne'nin aksi bir figürdür. Soğuk ve mesafelidir, çocukları yerine herhangi bir karar almasa da yine de birey olmalarına pek bir katkı sağlayamamış bir babadır.

Nermin Bayrakçı, kocasıyla arasında duygusal bir ilişki bulunmamasına rağmen, kocasına benzeyen oğluna aşırı bağlılık gösteren bir annedir, kontrol eder, aşırı şefkat gösterir ve her şart ve koşulda kendi "kü̧̈ük oğlu" olmasını ister. Buna karşın, ilgi ve sevgiye ihtiyaç duyan Tarık'a hiçbir sorun yokmuş gibi umursamaz davranmaktadır. Bu umursamazlık, gizleme dürtüsünden ileri gelmez, Cevdet'inki gibi şefkatli veya umutlu (hastalıktan konuşulmazsa, hastalık önemsenmezse yok olacağına inanmak) bir örtbas etmek çabası değildir, Nermin aslında Tarık’ı umursamamaktadır. Sorunlu bir çocuktur, Nermin de bunun farkındadır, temel ihtiyaçlarını karşılayacaktır ancak şefkat göstermeyecektir. Nermin ve Tarık arasında gerçek bir bağ oluşmamıştır. Nermin'in Tarık'la kurduğu bağ, Cevdet'le arasındaki kadar yapay bir bağdır. Tarık'a olan bu tavrına karşın, Nermin, Taner için bir polisi yaralamaya kadar uzanan bir fedakârlık listesi oluşturmuş- 
tur. Taner'in neye ihtiyacı varsa Nermin onu sağlar ya da Cevdet'in sağlamasına sebep olur. Silah, para veya cinayet örtbas etmek bu ihtiyaçlardan bazılarıdır. Oyunda Anne karakteriyle bulunan Nermin, dizidekine kıyasla daha tipik bir annelik sergiler. Çocuklarını korumaya çalışan ve onların suçlarını kafasında hafifletmeye gayret eden 60 yaşlarında bir kadındır. Çocuklarına zarar gelmesini her şeye rağmen önlemek istemektedir. Buna karşılık oğullarından bir yakınlık görmemektedir. İkisi de ruhsal açıdan sağlıksız iki oğlu vardır. Bu durumun sebeplerinden biri Anne'nin fazla korumacı tavrı olarak görülebilir. Normal bir aile hayatına sahip değildir. Baba, soğuk ve mesafelidir, ailesiyle bir şey paylaşmaktan zevk almaz. Bu şartlarda, kendisine fazladan biçtiği roller, oğullarının karar alma mekanizmasını etkilemiştir. İlişkileri bazında da başarısız olan oğulları, Anne için büyük bir hayal kırıklığına dönüşmüştür. Abi'nin ölümüyle birlikte, hayatını sürdüremez. Adam ve Baba'yı baş başa bırakarak ölür.

Oyunda ise Anne ve Baba'nın işaret ettiği aile profili, oyun kişilerinin, özgüvensiz, fevri, suç karşısında sorumluluk alamayan kişiler olmalarına neden olmuştur. Bu anlamda, yazar, aileyi hem sığınılacak bir yer, hem de Abi ve Adam'ın ruhsal problemlerinin temel kaynağı olarak göstermiştir. Birey olabilmeyi, bağımsız olarak kendini var etmeyi başaramamış Adam ve Abi, hayatlarındaki kadınlara duydukları bağımlılık sonucunda felaketlerine sürüklenmiş olurlar.

Tarık Bayrakçı, duyguları ve davranışları üzerindeki hakimiyeti sınırlı bir karakterdir. İnsan ilişkilerine de yansıyan bir durumu, onu zaman zaman aciz, zaman zaman hırçın kılmaktadır. Abisinin tanımlamasına göre, serbest bırakıldı̆̆ takdirde her şeyi en iyi şekilde yapabilir ancak üzerinde bir baskı veya sorumluluk beklentisi hissettiğinde mutlaka başarısızlığa uğramaktadır. Askerlikte, evlilikte ve çalışma hayatında, Tarık'ın düzenini bozan hep insanların ondan beklentileri olmuştur. Sosyal olarak bir tek ailesinde bu baskıyı yaşamamıştır, babasının her hareketini tolere eden tavrı ve annesinin ondan hiçbir şey beklemeyişi bir anlamda kurtarılmış bir bölge yaratmıştır Tarık'a. Ruhsal sorunlarının büyümesine neden olsa da kendini sorumluluktan uzak konumlandırabildiği tek yer ailesinin yanıdır. Gerçeklerden habersiz bir karakter olan Tarık, ne karısını öldüremediğini bilir, ne de abisinin ölmediğini... Babasının korumacıllğı ve hastalığının altında sıkışıp kalmıştır. Kendisine belirlenen sınırlarda yaşar, özgür olduğunu düşündüğü anlarda bile özgür değildir. Özgürleşme çalışması ve hayatı adına kendi verdiği belki de ilk karardır ailesini öldürmesi ve kendini öldürme denemesi. Annesi ve abisini öldürmeyi başarır ancak asıl kısıtlayıcısı babasını öldürememiştir. Bu öldürme anına kadar gerçekte en masum karakterdir ancak -me- 
sela- Emel'in perspektifinden son derece suçludur. Emel'e çok aşıktır, kendisine rağmen Emel için iyi bir koca olmaya çalışır. Ancak psikozları buna engel olmaktadır, Emel gerçekleri fark ettiğinde ondan uzaklaşmış, kontrolünde olmayan bu durum Tarık için yıkıcı olmuş ve tam bir çöküşe uzanacak olan olayları başlatmıştır. Tarık'ın oyundaki karşılığı olan Adam ise, 30'lu yaşlarda, karısına aşık biridir. Karısıyla arasında bir sorun olmuştur ancak, yazar tarafından bu oyunda verilmez. Karısı ve babası tarafindan işlemediği cinayetlerle suçlanır. Oyundaki diğer tüm kişiler, Adam'la ilişkileri bağlamında konumlandırılırlar, isimlerini Adam'ın hayatına dahil olma biçimlerinden alırlar. Adam, sürekli suçlansa da aslında oyunun tek masum kişisidir. Karısı tarafından aldatılmış, abisinin işlediği cinayet yüzünden karısı tarafından suçlanmış, karısının ölümü dolayısıyla babasınca dışlanmış bir karakterdir. Adam'ın, karısına uyguladığı şiddet dışında, oyun zamanı içinde herhangi bir çizgiyi aşmışlı̆̆ı yoktur. İdeal biri değildir ancak, bir katil de değildir Adam. Kendini ifade etme engeli, yaşadıklarının gerçekliğini saptamadaki başarısızlığı onu kabul görmekte zorlanan bir oyun kişisine dönüştürmektedir.

Emel, babasız büyümüş bir kadındır. Tarık'la tanıştıktan kısa süre evlenmişlerdir, babasız büyümesinin etkisiyle, kayınpederine oldukça sempatiyle yaklaşmaktadır. Bir aile arayışında olduğundan Rüya'nın aksine iyi bir gelin olma potansiyeli taşımaktadır. Emel'in yıkımını ve Tarık'tan uzaklaşmasını başlatan süreç, her ne kadar temelde Tarık'ın psikozlarını fark etmesi olsa da aslında ailesinin bu konuya yaklaşımı ve bu sebepten Tarık'a yardım etmek konusunda çaresiz kalışı gerçek kopuşu yaratmıştır. Hem Tarık'la ilgili sorunlarını çözmesi için yönlendirdiği (Selim'in) ablası, hem de yakın duruşuyla Selim, Emel için ilgi çekici olmayı başarmıştır. Emel için saf demek mümkündür, gayreti sevilmek üzerinedir, yaşamında "tuhaf" olanı rastlantı olarak yorumlama eğilimindedir. Üç ay içinde alelacele gerçekleşmiş bir evliliğ̣i, bir aileye sahip olmak olarak yorumlaması veya Selim'in ablasına terapide bahsettiği kitabın, Selim tarafından hediye edilmesini tuhaf bulmaması bu yargıyı örneklemek için uygundur. Tarık'tan da, Selim'den de beklentisi başlangıç için ortaktır, mutlu, huzurlu bir hayat, bir de aile. Her ne kadar Selim'in gerçek niyetini anlayamadan hayatını kaybetmişse de, bu beklentilerini karşılama ihtimali olan birine yaklaşmasının hızlı ve kolay olduğu görülmektedir.

Oyunda, Kadın, Adam'ın karısıdır, genç ve güzel bir kadındır. Aşık'la tanışmasının ardından başlayan ilişkisi onu heyecanlandırmaktadır. Kadın'la ilgili bilgilerimiz kısıtlıdır. Samimiyetsiz bir karakter olduğu düşünülebilir. Bu vurgu, Aşık'la yaptığı telefon konuşmasında, Aşık tarafından kendisine sarf edilen özlem sözünün, kocasına bıraktığı tele- 
sekreter mesajında tekrarlamasıyla sağlanır. Kadın, ses kayıt cihazını fark ettikten sonra, cesur ve baskı1ı bir biçimde Adam'ın üstüne gider. Adam'a, Aşık'ı öldürme suçunu yakıştırır ve suçu kabul etmesini bekler. Adam'ı aldatmış olmasından kaynaklanan suçunu göz ardı etmektedir. Kocasına, sevgilisinin hesabını sormakta sakınca görmez. Adam'ın bu noktada, son andaki şiddet tepkisine dek beklenmedik tepkiler verdiği de gösterilir.

Selahattin, Yusuf'un amiri, Cevdet'in eski çalışma arkadaşı bir komiserdir. Cevdet'in söylemlerinden kadınları dövmekten haz aldığını anlarız, Rus hayat kadınlarına ve Rüya'ya uyguladığını bildiğimiz şiddetin kaynağını tanımlayabilecek kadar karakteri tanıyamasak da, gücünü kötüye kullandığı aşikardır. Yusuf’u kendisinin Rüya'yla ilişkisinin dinamiklerine veya Cevdet'le iletişiminin boyutuna göre davaya sürmesi veya alıkoymas1 bu duruma örnektir. Babacan biri gibi görünür, dizinin son bölümüne dek gerçekliğini seyirciye ve özellikle Yusuf'a sezdirmez. Rüya'yla ilişkileriyle ilgili bildiklerimiz Taner'in anlattığı kadardır. Yalnızca, Taner'in Rüya'yla son konuşmasından sonra, Yusuf'u Taner'i gerekirse öldürmek üzere köye yollaması belirli bir kıskançlı̆̆ı tanımlar.

Selim, kendi halinde yaşayan, obsesyonları olan (şeker yemesi gibi) bir yazardır. Gözlem yoluyla romanını bitirebileceğine inanmıştır. Bardaki kavgaya şahit olduğunda, Tarık'ın iyi bir malzeme olacağını fark eder. Emel'e yaklaşır. Emel'in boşlukta oluşunu doğru hamlelerle kullanır. Selim, masumiyetin sınırını, gözlemin sınırını geçtiğinde aşmıştır. Mahremiyeti olan terapiyi kaydetmek, Tarık ve Emel'in evine gizlice girmek onun sonunu hazırlar. Korkak biridir, mücadele etmek yerine kaçmayı seçer. Özellikle yaklaşmadığı sürece, insanların hayatında fark edilmez bile, görünmezdir. Fakat Emel'e olan yaklaşımında görüldüğü gibi insanlara doğru stratejiyle yaklaşmayı ve kendini kabul ettirmeyi bilmektedir. Oyundakine göre daha manipülatör bir karakterdir.

\section{Uyarlamada Oluşan Farklılıklar}

Bayrak'ta oyun kişileri, özdeşlik kurulamayacak kişiler olarak yapılandırılmıştır. Seyirci, suçlu veya suça ortak olan, sürekli olarak zaaflarıyla var olan oyun kişileriyle karşı karşıyadır. Suç, suçlu ve suçun sınırları oyunda tartışmaya açılır. Oyunun ana çatışması suç işleme- suçu saklama etrafında şekillenir. Karakterlerden hiçbiri suçtan azade değildir. Yan çatışmalarda, kadın- erkek, sadakat- sadakatsizlik çatışmaları dikkat çeker. Abi ve Adam'ın aldatılışları, kardeşler arasında bir paralellik oluşturmaktadır. Kendi “intikamını" almayı başaramamış Abi, kardeşinin intikamını kendi yerine alır. Adam, oyun boyunca kurtulamaz ve sürekli olarak birine muhtaç olarak varlığını sürdürür. 
Karakterlerin tümünün kendisine ait bir trajedisi vardır. Abi'nin kendisini aldatan karıs1nın, sevgilisinden şiddet görmesine rağmen sürekli sevgilisine dönmesi, Abi'nin büyük trajedisidir. Eski bir kanun adamı olan Baba'nın iki oğlunun da karıştığı cinayet suçları Baba'nın trajedisidir. Her şeyden koruduğu oğullarının, felaketlerini önleyememek Anne'nin trajedisidir. Aldatılması karşısında karısını öldürecek kadar gözü dönen Adam'ın karısını öldürmeyi beceremeyişi Adam'ın trajedisidir. Kendini yazıya adamış romancının, gözlem sınırlarını aşıp girdiği evde, karısının sevgilisinden hıncını alamayan Abi'yle karşılaşması trajedisini oluşturur. Kadın için ise, kocasına sevgilisinin hesabını sorması ve Adam'ın elinden kurtulmayı başarıp, ardından katil sandığı Adam'ı abisine kötülemesi bir trajediyi oluşturur. Oyun kişileri, trajedileri içine sıkışmış durumdadır, içinden çıkmaları mümkün olmayan bu durumları onları kapana kısılmış, çözümsüz kılmaktadır. Hiçbir olası çözüm, karakterleri sıkıştıkları yerden çıkaramaz. Oyun ölüleriyle birlikte kendilerini o eve gömmek zorunda kalacak oyun kişilerinin çöküşüyle noktalanır.

İlk tabloda oluşturulan gergin atmosfer, ikinci tabloda Kadın'ın motivasyonunun tam olarak algılanamayışıyla yapaylaşmıştır. Oyun kişilerinin, tam anlamıyla karakter özellikleri gösterememesi oyunu dramatik anlamda zayıflatmaktadır. İki cinayet ve bir kazayla yaşamları tümden sarsılan aile bireyleri, sadece karanlık yönleriyle gösterilmektedir. Oluşturulan durum bazında bu normal karşılanabilse de, ilk tablodaki geçmişe dair detaylar, rutini korumaya gayret eden Anne karakterinin eksikliği oyun boyunca hissedilmektedir. Geçmişe dair aydınlatılmayan detaylar ve/veya karakterlerin bazı eylemlerinin altındaki motivasyonun açıklanmaması oyun için bir sorun oluşturmaktadır. Bu eksikliklerin giderildiğini düşündüğüm dizi, bu anlamda da incelenmeye değer bulunmuştur.

Diziye uyarlanırken genişletme işlemine tâbi tutulan oyunda, oyun içinde anılmayan pek çok mekân ve olay açıklanmış ve hikâyenin gücünü arttırmıştır. Örneğin, Emel'in yasak aşk1, birden bire olmamış, tüm umutlarının tükendiği yerde başlamıştır. Bu da oyundaki Kadın karakterine göre Emel'i özdeşlik kurulabilecek, seyirci tarafından anlaşlabilecek bir noktaya taşımıştır.

Berkun Oya, oyununu uyarlarken, görsel olanaklardan fazlaca faydalanmış, oyunda görmenin mümkün olmadığı, oyunun anlamını destekleyen, açıklayan, tamamlayan sahnelere yer vermiştir. Örneğin, Taner'in eşinin bir karakter olarak dahil olmasıyla Rüya ve diğer karakterler arasında geçen sahneler, ailenin iç dinamiklerinin daha net görülmesini sağlamış, dramatik yapıyı güçlendirmiştir. 
Oya'nın oyununu uyarlarken yaptığı en radikal değişiklik, eklenen karakterler olmuştur. Oyundaki adli vakanın çözümü böylece sağlanmıştır. Sadece aile içinden değil, polis gözünden de saklanan gerçekliğe bakmak mümkün olmuştur. Aynı zamanda daha önce de belirtildiği gibi, Yusuf karakteri, seyircinin özdeşleşme ilişkisini kuracağı karakter olmuştur. Davis'in söylediği gibi “(...) çekici olan karakterle özdeşleşme eğilimimiz de vardır ve çekiciliğin temel öğesi de karakterin yaptığı konuşmalarda yatar” (Davis, 2015, s. 129).

Yusuf'un konuşmaları, evliliğini kurtarmak ve adaleti sağlamak yönündedir. Bu iki konu da seyircinin ondan yana olmasını sağlamaya olanak sağlar. Diğer karakterlerin ideallikten uzak durumları da, seyircinin Yusuf'la özdeşleşmesini alternatifsiz olarak sağlamaktadır. Yusuf'un varlı̆̆ıyla aile, polisin gelmesi ihtimalinden, polisle başa çıkma zorunluluğuna geçer. Bu da oyundakinden daha güçlü bir dramatik malzemeyi oluşturmaktadır. Ayrıca, uyarlamada eklenen diğer karakterler, Yusuf'la birlikte gelmişler, Yusuf'un çevresindeki insanlardan oluşmuşlardır. Yusuf'un karısı ve kızı, Yusuf için değerli olanları temsil edip, onu daha da canlı bir hale sokarken, amiri, olaylarla da ilişkili hale getirilerek, dizinin sonundaki sürprizi hazırlar. Bunun dışında oyunda görmediğimiz Rüya, oyundaki hikâyesiyle, dizide yer almaktadır. Rüya'yı görmek, Taner'i daha canlı bir oyun kişisine dönüştürür. Bu kez, oyundakinin aksine, Taner'in anlattıklarını sadece onun perspektifinden dinlememekte, yaşadığ ilişkinin iç dinamiklerini görme fırsatı da buluruz. Cinayeti işleme sebebini, daha açıkça görmemizi sağlayan bu durum, Taner'in karakterini de, oyundaki karşılığı olan Abi'den daha güçlü bir dramatik altyapıya sahip kılmaktadır.

Tarık ve Emel'in ilişkisi de, hem zamansal hem de uzamsal genişlikten faydalanılarak açımlanır. Oyunda, Emel'in yasak ilişkisinin nedenlerini görmememize rağmen dizi, Emel'in bu ilişki içine itildiğini göstermektedir. Bayrakçı ailesi, ilgisiz ve kabullenmez tutumlarıyla, Emel'i yalnız bırakmış, Emel de Tarık'ın durumuyla başa çıkacak gücü bulamayarak, kendisine ilgi gösteren Selim'i hayatına almıştır.

Oyunun aksine, dizi, Emel ve Taner'le empati yapabilmek için gerekli altyapıyı sunar. Karakterlerin davranışları altındaki motivasyonları açıklandığı için onların davranışlarını anlamak ve kimi zaman onlara hak verebilmek mümkün olmuştur. Oyunda Anne, Baba, Abi ve Adam'dan oluşan aile, annenin çocuklarını korumaya çalıştığı, babanın çocuklarına daha mesafeli yaklaştığı, daha tipik diyebileceğimiz bir Türk ailesidir. Fakat dizide, anne ve babanın çocuklara yaklaşımı daha özellikli ve özel çizilmiştir. Ailenin 
süregelen kopukluğunun altı daha net çizilmiş, Cevdet- Tarık ve Nermin-Taner arasındaki belirlenmiş saflar, ailenin yapısını daha ilgi çekici ve ilginç kılmıştır. Tarık'ın hastalı$\breve{g}$ 1, ailedeki dengesizliğin temelini oluşturmuştur.

Tarık'ın belirsiz ruhsal problemi, gördüğü psikozlara bağlanmıştır, bunlar da ekrana getirilmiş, Emel'in süreci, seyirci için de görünür kılınmıştır.

Bunların dışında, oyun ve dizi arasında argo ve küfür kullanımı konusunda da bir ayrım vardır. Oyunda diziye göre çok daha az argo ve küfre yer verilmiştir. Dizi ise, hem doğallığı desteklemek, hem de daha derinlikli olan karakterlerin gereksinimini karşılamak üzere, argo ve küfre daha çok yer vermektedir. Bu noktada, internet dizisi olması ve sansürsüz oluşunun hem tanıtımlarında hem de sosyal medyada sıkça vurgulanmasına da değinmek gerekir. Günümüz televizyonları göz önünde bulundurulduğunda, sansürsüz kelimesi, alkolün açıkça gösterilebildiği, küfür ve argo kullanımının olduğu, cinselliğe ya da çıplaklığa yer verebilen bir yapıyı işaret etmektedir. Masum, küfür, argo ve alkol kullanımıyla sansürsüz sınıfına girmiştir. Tüm bunlar yaratılan karakterlerin, karakter özelliği göstermesine fayda sağlamış, doğallıklarını arttırmıştır.

\section{Sonuç}

Bayrak'ta idealize edilmiş herhangi bir karakter bulunmaz, hiçbir oyun kişisi bu tip meziyetlere sahip değildir. Yazar burada, tüm oyun kişilerini zaaflarıyla var etmiştir. Her biri birer zaaf yumağıyken, olumlu özellikleri son derece c1lızdır. Bu Berkun Oya'nın oyun yazarlığında tercih ettiği bir yaklaşımdır. Diğer oyunlarında da (Babamın Cesetleri, Güzel Şeyler Bizim Tarafta, Yangın Duası) idealize edilmiş veya ideal davranan karakterlere rastlanmaz. Karakterlerini içine soktuğu durum gereği, iyi niyetli davransalar dahi, bir kötülüğe, bir açmaza yol açmaktadırlar. Berkun Oya'nın karakterleri, yazarları tarafından köşeye sıkıştııılmış, içine düştükleri durum karşısında çabalayan ama sadece bataklıkta çırpınan karakterlerdir. Bu yeniklik oyun boyunca sürmekte, çıkış yolu karakterlere sunulmamakta, her bir umut ışığı, kurtuluş yolu yazar tarafından engellenmektedir. Daha önce de değinildiği gibi, tüm karakterler bir şekilde suçludurlar.

Bayrak'ta da durum değişmez. Kendi vicdanına, toplumsal konumuna, yasaya ters düşen, iyi yanları c1lız altı kişiyi görürüz. Kendi hapishanesine sıkışan bu altı kişi, oyun boyunca farklı kombinasyonlarla sürekli olarak hesaplaşırlar. Oyun başladığında olay yaşanmıştır, sonuçlarıyla yüzleşilmektedir. Bu yüzleşme ve sonrasında olaya ilişkin geri 
dönüşleri içeren tablolarla parçalar birleşir. Olaylar sıralı ilerlemez, bu merak unsurunu seyirci için canlı tutmak ve yazarın hedeflediği gerilimli atmosferi sağlamak içindir.

Bayrak'ta gerilim ve merak olayın gizlenmesiyle oluşturulur, buna karşılık Masum'un gerilim ve merak yaratan öğesi olayın gizlenmesi değildir. Masum'un gerilimi, karakter ilişkilerinin çözümlenmesinde gizlidir. Masum' da gizemi sürdüren birbirine birden fazla şekilde temas eden karakterler arasındaki ilişki ağıdır. Oyunda 'bir şey' olduğunu bilir ancak o 'şeyin' ne olduğunu bilemeyiz. Dizide ise, örneğin, Taner'in ölmediğini çok erken öğreniriz ancak bu kez Selim ve Taner ilişkisi sunulur seyirciye merak unsuru olarak. Şaşırtıcılık, olaydan öte, karakterin gizemli bağından doğar. Nermin'in sonraki adımda ne yapacağı başına gelen olaydan daha büyük bir meseledir.

Diyebiliriz ki oyun, duruma odaklanırken, dizi karakterlere odaklanır. Yazarın burada hem oyun için zayıf bıraktığı karakterlerini zenginleştirmeyi, hem de dizi süresini en iyi şekilde kullanmayı hedeflediği düşünülebilir.

Tüm veriler ışığında, bir uyarlama olarak bakıldığında, Masum, nitelikli bir tiyatro uyarlaması olarak görülmelidir. Hatta, oyunun zaaflarının yazar tarafından giderilerek uyarlanması, dizinin gücünü arttırmaktadır. Oyuncu kadrosunun özenli seçimi diziyi ayrıca cazip kılmakta, ülkenin en popüler oyuncularından oluşan kadroyu izlemek, seyirciyi birçok açıdan tatmin etmektedir.

Akyürek ve Orhon, dizide söz yoğunluğuna değinirken, günlük dizilerle tiyatro oyunları arasında, 'gelişimin tüm devinimlerini açıklayan konuşma örgüsü' arasında bağ kurmuşlardır. Gece kuşağı hariç, dizilerin bu yapıyla seyirciyle buluştuklarını belirtirler (Akyürek ve Orhon 2009, s. 130). Ancak bu tespitin yapıldığg 2009 yılından günümüze gelindiğinde, uzun reklamlarla birlikte iki buçuk saate ulaşan diziler, tamamen bu tip konuşma örgüsüne sahip olarak oluşturulmaktadırlar. Masum ve muadillerinin kazandığı en büyük başarı da, bu dizilerin süresi ve süresinin dizi senaryosuna verdiği zarardan azade olarak seyirci tarafından kabullenilmesi olmuştur. Buna karşın, Masum, BluTV'nin ardından Kanal D'de yayınlandığında başarısız reytingler yakalamıştır. Bu internet televizyonu kullanıcıları ve televizyon kullanıcıları arasındaki farkla açıklanabilir. Yine de karșın ülkemizin ilk profesyonel internet dizisi olarak tanımlanan Masum, BluTV CEO'su, Aydın Doğan Yalçındağ, rakam vermemekle birlikte dizinin beklentileri aştığını belirtmektedir (Webrazzi, 2017). 
Dünyada kendi kitlesini oluşturan ve yavaş yavaş televizyon yayıncılığının yerini alan internet televizyonculuğunun bu ilk adımı olan Masum'un gerek niteliği gerekse başarısıyla iyi bir öncül olduğunu söylemek mümkündür.

Türkiye'deki dizi sektörünün, senaryo niteliğini kısıtlayan etkenlerinden uzak, nitelikli üretimlere zemin hazırlayan bu dizinin en büyük başarısı, ardından gelecek olan dizilerin yolunu açmış olması olmuştur. Bir ilk olarak son derece başarılı olduğunun altı çizilmelidir.

Hakem Değerlendirmesi: Dış bağımsız.

Çıkar Çatışması: Yazar çıkar çatışması bildirmemiştir.

Finansal Destek: Yazar bu çalışma için finansal destek almadığını beyan etmiştir.

Peer-review: Externally peer-reviewed.

Conflict of Interest: The author has no conflict of interest to declare.

Grant Support: The author declared that this study has received no financial support.

\section{Kaynakça/References}

Akyürek, F. v. (2009). Dizi Senaryosu Yazmak. İstanbul: MediaCat Kitapları.

Bulut, S. (2017). Türk Tiyatrosunda Uyarlama (1860-1923). Ankara: Gece Kitaplığı.

Field, S. (2013). Senaryo: Senaryo Yazımının Temelleri. (Ş. Erol., Trans.) İstanbul: Alfa Basım Yayın Dağıtım.

Miller, W. (2012). Senaryo Yazımı Sinema ve Televizyon için. (Y. Büyükerşen, N. Esen , \& Y. Demir, Trans.) İstanbul: Hayalperest Yayınevi.

Netflix Inverstor Relations. (2020). Netflix’s View: Streaming Entertainment is Replacing Linear TV (2020, 21 Ocak). Erişim Adresi: https://ir.netflix.net/ir-overview/long-term-view/default.aspx

Oya, B. (2017). Esneyen Boşluk. İstanbul: Everest Yayınları.

Seger, L. (1992). The Art Of Adaptation: Turning Fact and Fiction into Film. New York: Owl Books.

Truffaut, F. (2018). Hitchcock. (İ. Hizlı, Trans.) İstanbul: Hayek Kitap.

Webrazzi. (2017, 21 Nisan). Yeni Nesil TV Platformları- Webrazzi Mobil 2017 [Video]. Erişim adresi: https://www. youtube.com $/$ watch?time_continue $=913 \& v=9$ oqDibda $2 q Y$ 
